\section{principles calculations}

\title{
New constraints on Xe incorporation mechanisms in olivine from First-
}

Céline Crépisson ${ }^{\mathrm{a},}{ }^{*}$, Marc Blanchard $^{\mathrm{b}}$, Michele Lazzeri $^{\mathrm{c}}$, Etienne Balan ${ }^{\mathrm{c}}$, Chrystèle Sanloup $^{\mathrm{a}}$ 列

a'Sorbonne Universités - Institut des Sciences de la Terre de Paris (ISTeP), UPMC Université Paris 06, CNRS, UMR 7193, 4 place Jussieu, 75005, Paris, France

${ }^{\mathrm{b}}$ Géosciences Environnement Toulouse, Observatoire Midi-Pyrénées, CNRS UMR 5563, IRD

UR 154, Université Paul-Sabatier, 14 avenue Edouard Belin, 31400 Toulouse, France

'Sorbonne Universités - Institut de Minéralogie, de Physique des Matériaux, et de Cosmochimie (IMPMC), UPMC Université Paris 06, UMR CNRS 7590, Muséum National d'Histoire Naturelle (MNHN), UMR IRD 206, 4 place Jussieu, 75005 Paris, France

*Corresponding author. Address : Céline Crépisson, Institut des Sciences de la Terre de Paris (ISTeP), UPMC Université Paris 06, Case 110, 4 place Jussieu, 75005 Paris, France. Tel.: +33 1442760 64. Email : celine.crepisson@upmc.fr 
Storage of Xe at depth in silicate minerals has recently been proposed to explain the low Xe abundance in the Earth's and Mars' atmospheres compared to other noble gases (the so-called 'Missing Xenon' issue). Evidences for incorporation, and thus reactivity of Xe in olivine at high pressure and high temperature are based on variations in cell parameters and the appearance of a new Raman band. To constrain the, so far only hypothetical, Xe incorporation mechanism in olivine, we theoretically investigated models of Xe-bearing olivine using density functional theory. Three types of incorporation mechanisms are tested: Xe for Si and Xe for Mg substitutions, and interstitial Xe. Xe for Si substitution, implying an oxidation of $\mathrm{Xe}$, is found to be the only mechanism consistent with experimental observations, leading to an increase of cell parameter $a$ and the appearance of a new Raman band around $720-750 \mathrm{~cm}^{-1}$ associated with $\mathrm{Xe}-\mathrm{O}$ stretching vibrations. Raman spectroscopy makes it possible to identify Xe incorporation site, even at low Xe content, due to high Xe polarizability. An estimation of Xe content in olivine, based on present work and previous in situ experimental results, shows that up to 0.4 at \% Xe could be stored in olivine at depth. 


\section{INTRODUCTION}

Noble gases, highly volatile and poorly reactive elements, are of particular interest in Earth and planetary sciences to study and date the formation of the atmosphere (Avice and Marty, 2014) or to trace magmatic sources and degassing processes. Xenon, the heaviest of the noble gases, with nine stable isotopes $\left({ }^{124,126,128,129,130,131,132,134,136} \mathrm{Xe}\right)$, is at the heart of a long-standing question, the so-called 'Missing Xenon' issue. Elemental Xe, compared to other noble gases, is missing in the atmospheres of the Earth and Mars relative to chondritic abundances (Anders and Owen, 1977). According to Ozima and Podosek (1999), around 90\% of Earth's primordial Xe is missing from the atmosphere. In addition, the atmospheres of Earth and Mars present a strong deficit in Xe light isotopes $\left({ }^{124,126,128} \mathrm{Xe}\right)$ (Krumennacher, 1962). Some Archean rocks present a Xe isotopic composition falling in between primitive chondritic and present-Earth atmospheric values, with an enrichment of the light nonradiogenic Xe isotopes relative to the present-Earth atmosphere of $2.1( \pm 0.3) \% \mathrm{amu}^{-1}$ for a 3.5 Gy barite (Pujol et al., 2009), and $1( \pm 0.5) \% \mathrm{amu}^{-1}$ for a $3.0( \pm 0.2)$ Gy quartz (Pujol et al., 2011). These findings indicate a storage and fractionation of Xe throughout the Archean (Avice and Marty, 2014) which could continue nowadays through subduction processes (Holland and Ballentine, 2006). Recently, a number of studies have supported storage of Xe in silicates at depth. Xe oxides have been synthesized: $\mathrm{XeO}_{2}$ at ambient pressure and temperature (Brock and Schrobilgen, 2010), and $\mathrm{Xe}_{3} \mathrm{O}_{2}$ and $\mathrm{Xe}_{2} \mathrm{O}_{5}$ at respectively $97 \mathrm{GPa}$ and $83 \mathrm{GPa}$, and at around $2000 \mathrm{~K}$ (Dewaele et al., 2016); as well as a Xe-bearing perovskite (Britvin et al., 2015) at ambient pressure. Furthermore, experiments brought evidence of Xeincorporation in $\mathrm{SiO}_{2}$ phases (Sanloup et al., 2002, 2005) and olivine (Sanloup et al., 2011) at crustal and upper mantle P-T conditions. If the presence of pure Xe oxides in the Earth is unlikely, storage in silicates as a trace element may be a significant phenomenon in $\mathrm{Xe}$ 
retention at depth. Furthermore, a granite from the Sudbury impact structure (Kuroda et al., 1977) as well as siliceous sediments (Matsubara et al., 1988; Matsuda and Matsubara, 1989) have been found to be enriched in Xe by 2 to 3 orders of magnitude.

A detailed understanding of incorporation mechanisms of $\mathrm{Xe}$, and reliable values of $\mathrm{Xe}$ solubility in minerals are presently needed to quantify the role of Xe incorporation in minerals in the context of the 'Missing Xenon' issue at the Earth's scale. Reliable partition coefficients are also needed to understand the fate of Xe in melting and crystallizing processes (from the magma ocean era to the current day magmatic processes). All available data on Xe-solubility in minerals are based on ex situ analyses of Xe-saturated samples, synthesized at high temperatures and, in some cases, at high pressures. Measured Xe solubility in olivine varies from 6.5 ppb down to 0.67 ppt (Broadhurst et al., 1992; Heber et al., 2007; Hiyagon and Ozima, 1986). Similarly, olivine melt partition coefficient varies from 90 to $6.10^{-4}$ (Broadhurst et al., 1992; Hiyagon and Ozima, 1986; Heber et al., 2007) and the compatibility (or not) of Xe in minerals remains controversial. In samples recovered from high pressure and temperature experiments, $\mathrm{Xe}$ is at least partly located in gas bubbles, and inconsistencies in Xe solubility and partition coefficient mainly stem from whether or not bubbles are analyzed, keeping in mind that their sizes range from the $\mathrm{nm}$ to the $\mathrm{mm}$ scale, and that part or all of these bubbles may form upon quenching to room conditions. Consequently, the evaluation of Xe content should be preferentially based on in situ measurements as proposed in the present study.

Recent experiments have focused on the incorporation mechanism of $\mathrm{Xe}$ in olivine, one of the most widespread terrestrial minerals. Sanloup et al. (2011) studied Xe-bearing San Carlos olivine up to $7 \mathrm{GPa}$ and $2000 \mathrm{~K}$ by in situ x-ray diffraction and Raman spectroscopy reporting shifts of lattice parameters in presence of Xe at high pressure and for temperatures above Xe melting point. Cell parameter $a$ increases, $c$ decreases (although $c$ is strongly 
101 temperature dependent) while $b$ is not affected. This lattice distortion was interpreted as

102 potentially due to Xe incorporation on Si sites, as Si release from olivine was observed. A

103 new Raman mode, in presence of Xe, (disappearing within few minutes after quench) was

104 also observed at $786 \mathrm{~cm}^{-1}$ in presence of Xe at $0.9 \mathrm{GPa}$ after heating at $1800 \mathrm{~K}$. This new

105 Raman band is close to the stretching of $\mathrm{XeO}_{4}$ at $776 \mathrm{~cm}^{-1}$ (Gerken and Schrobilgen, 2002),

106 and is in the Si-O stretching region of olivine (Noël et al., 2006). As for other heavy rare

107 gases, Ar was not observed to substitute to Si in olivine up to $7 \mathrm{GPa}-2000 \mathrm{~K}$ (Sanloup et al.,

108 2011). In the absence of studies devoted to the incorporation of $\mathrm{Kr}$ in minerals at depth, we

109 can temporarily conclude that this mechanism is specific to Xe and of major relevance to the

110 'Missing Xe' issue.

111 First-principles calculations represent a powerful complementary approach to identify

112 incorporation sites of trace elements in minerals. Regarding $\mathrm{Xe}$ in silicates only two

113 theoretical studies are so far available. Probert (2010) investigated different incorporation

114 mechanisms of Xe in $\alpha$-quartz, but the lack of related measurements prevents definitive

115 conclusion. Kalinowski et al. (2014) investigated Xe incorporation in fibrous silica, which can

116 be found on Earth in moganite or chalcedoine (Hopkinson et al., 1999). Computed Raman

117 spectra of Xe-bearing fibrous silica possibly reproduce observations for Xe-rich quartz

118 (Sanloup et al., 2002) and $\mathrm{XeO}_{2}$ (Brock and Schrobilgen, 2011).

119 In the present work, we study the structure, stability and vibrational properties of

120 different incorporation sites of Xe in olivine, by means of first-principles calculations based

121 on density functional theory (DFT). These theoretical results are then compared to the

122 experimental data of Sanloup et al. (2011) to infer potential mechanisms of Xe storage in

123 Earth's interior.

\section{METHODS}


Various systems are investigated: two reference compounds $\left(\mathrm{XeO}_{4}\right.$ molecule, $\mathrm{Xe}_{3} \mathrm{O}_{2}$ condensed phase); pure forsterite $\left(\mathrm{Mg}_{2} \mathrm{SiO}_{4}\right.$, the Mg-rich end member of the olivine series,); Xe-bearing forsterite in which one Xe atom substitutes one $\mathrm{Si}($ or $\mathrm{Mg}$ ) atom or in which one $\mathrm{Xe}$ atom is added at an interstitial position. In all cases, the charge of the simulation cell is neutral. Xe-bearing forsterite is simulated using supercells of various sizes: $2 \times 1 \times 2,4 \times 1 \times 2$,

$1323 \times 1 \times 3,4 \times 2 \times 4$ (with respect to the forsterite unit cell containing 28 atoms) corresponding to a concentration of approximately $0.89,0.45,0.40,0.11$ at $\% \mathrm{Xe}$ (or 5.5, 2.8, 2.5, $0.72 \mathrm{wt} \%$

134 Xe), respectively.

135 All calculations are done within density functional theory (DFT) and the generalized gradient 136 approximation (GGA-PBE) of Perdew et al. (1996), by using the PWscf code of the Quantum

137 ESPRESSO package http://www.quantum-espresso.org/; Gianozzi et al., 2009). Norm138 conserving pseudopotentials (Troullier and Martins, 1991) are used. Electronic wave139 functions (charge-density) are expanded up to an energy cut-off of 80 (480) Ry. Equilibrium 140 structures are obtained after full relaxation of atomic positions and cell parameters (total 141 energy is converged within $1 \mathrm{mRy} /$ atom and forces to less than $\left.10^{-4} \mathrm{Ry} / \mathrm{au}\right)$. Electronic k-point 142 sampling of $\mathrm{Xe}_{3} \mathrm{O}_{2}$ and pure forsterite uses $6 \times 16 \times 10$ and $2 \times 1 \times 2$ shifted grids, while that of the 143 Xe-bearing larger cells uses one shifted k-point. Spin polarized calculations were tested, 144 obtaining zero magnetic moments for all the systems. Vibrational properties (dynamical 145 matrices, dielectric constants, Born effective charges, and Raman tensor) are obtained within 146 the approach of Baroni et al. (2001) and Lazzeri and Mauri (2003). For Raman tensors and

147 effective charges calculations a finer k-point sampling is used $(4 \times 2 \times 4$ grid for pure forsterite 148 and a $2 \times 2 \times 2$ one for Xe-bearing forsterites).

149 For the Xe-bearing forsterites, actual DFT calculations of the dynamical matrices (and, thus, 150 of the interatomic force constants, IFCs) have been done only for the $2 \times 1 \times 2$ cell. To simulate 
151 larger cells, we have used a force-matching approach similar to that of Lazzeri and

152 Thibaudeau (2006). One considers a forsterite cell (larger than the $2 \times 1 \times 2$ cell) containing one

153 Xe atom: the IFCs among the atoms in the neighborhood of the Xe atom (a sphere centred on

154 the $\mathrm{Xe}$ atom with a $6.35 \AA$ radius i.e. containing $\sim 80$ atoms) are taken from the DFT

155 calculations done on the $2 \times 1 \times 2$ cell, the other IFCs (for atoms located further than $6.35 \AA$

156 from the Xe atom) are taken from pure forsterite bulk calculations.

157 In the following, calculated Raman spectra are done in a back-scattering geometry and, unless

158 otherwise stated, the spectra are obtained after averaging polarizations and sample orientation.

159 We note that for the kind of systems presently studied, vibrational frequencies are generally

160 underestimated by DFT-GGA calculations. To make the comparison with measurements

161 easier, all theoretical frequencies are multiplied by a factor 1.05 (in order to match the most

162 intense theoretical Raman bands of pure forsterite with the measured ones, Table S1) as in 163 Lazzeri and Mauri (2003).

164

165

\section{RESULTS}

166

167

\subsection{Reference compounds and pure forsterite}

As a test, we calculated the structure of the $\mathrm{XeO}_{4}$ tetrahedral molecule and $\mathrm{Xe}_{3} \mathrm{O}_{2}$ condensed phase (Table 1). For $\mathrm{XeO}_{4}$, Xe-O bond length is $2.0 \%$ larger than the experimental

171 value (Gundersen et al., 1970) whereas the one from Probert (2010) is 4.8\% larger (Table 1).

$172 \mathrm{Xe}_{3} \mathrm{O}_{2}$ was simulated at $97 \mathrm{GPa}$ using the orthorhombic Immm space group as predicted by 173 Hermann and Schwerdtfeger (2014) and synthesized by Dewaele et al. (2016). Bond lengths 174 are well reproduced (within $0.5 \%$ ) whereas cell parameters are slightly different (within $1751.5 \%$ ) (Table 1). 
Forsterite $\left(\mathrm{Mg}_{2} \mathrm{SiO}_{4}\right)$ has an orthorhombic structure with three distinct oxygen sites

178 (O1, $\mathrm{O} 2$ and $\mathrm{O} 3)$, two distinct magnesium sites $(\mathrm{Mg} 1$ and $\mathrm{Mg} 2)$ and one silicon site. Our

179 calculated cell parameters for pure forsterite $(a=4.78 \AA, b=10.25 \AA, c=5.99 \AA)$ are in good

180 agreement with single crystal x-ray diffraction measurements recorded on pure forsterite at

181 ambient conditions, i.e. $a=4.752(3) \AA, b=10.193(8) \AA, c=5.977(5) \AA$ (Hazen et al., 1976).

182 Similar values were obtained by previous studies using also GGA (which tends to increase

183 cell parameters) and similar computational parameters (Balan et al., 2011). Born effective

184 charges (Table S2) and calculated Raman frequencies of pure forsterite (Table S1) are in good

185 agreement with the ones calculated by Noël et al. (2006). Computed polarized Raman spectra

186 are in agreement with McKeown et al. (2011) (Fig. S1). The average Raman spectrum

187 compares well with the experimental spectrum of San Carlos olivine (Sanloup et al., 2011).

188 The presence of $\mathrm{Fe}$ in San Carlos olivine $\left(\left(\mathrm{Mg}_{0.9} \mathrm{Fe}_{0.1}\right)_{2} \mathrm{SiO}_{4}\right)$ does not significantly change the

189 average Raman spectrum compared to pure forsterite (Fig. 5).

\subsection{Xe incorporation models}

Three main types of $\mathrm{Xe}$ incorporation mechanisms are investigated: $\mathrm{Xe}$ for $\mathrm{Si}$

194 substitutions $\left(\mathrm{Xe}_{\mathrm{Si}}\right)$, $\mathrm{Xe}$ for $\mathrm{Mg}$ substitutions (in $\mathrm{Mg} 1$ and $\mathrm{Mg} 2$ sites) $\left(\mathrm{Xe}_{\mathrm{Mg} 1}, \mathrm{Xe}_{\mathrm{Mg} 2}\right.$ ), and $\mathrm{Xe}$

195 in interstitial site $\left(\mathrm{Xe}_{\mathrm{i}}\right)$. We relaxed atomic positions at constant volume for these four 196 mechanisms for 0.89 at \% Xe. No significant change was observed in the configurations of 197 Xe incorporation sites for more diluted defects $(0.45$ at $\%$ Xe or 0.40 at $\%$ Xe, depending on

198 the supercell) or for simultaneous relaxation of atomic positions and cell parameters. The

199 configurations and selected parameters of the four main Xe incorporation sites $\left(\mathrm{Xe}_{\mathrm{Si}}, \mathrm{Xe}_{\mathrm{Mg} 1}\right.$,

$200 \mathrm{Xe}_{\mathrm{Mg} 2}$ and $\mathrm{Xe}_{\mathrm{i}}$ ) are reported (Figs. 1, 2, 3) following simultaneous relaxation of atomic 201 positions and cell parameters at $0 \mathrm{GPa}$ for 0.89 at $\% \mathrm{Xe}$. CIF files for all configurations can 
202 be found in supplementary materials. One third of the trace of the Born effective charge 203 tensor $\left(Z^{\text {eff }}\right)$ is used to evaluate atomic charges, as discussed by Ghosez et al. (1998).

Xe incorporation sites can be described in terms of the closest surrounding oxygens.

\subsubsection{Most stable configurations of Xe incorporation sites}

For the most stable $\mathrm{Xe}$ for $\mathrm{Si}$ substitution, $\mathrm{Xe}$ is located on the face of the oxygen tetrahedron (Fig. 1). Xe is surrounded by one $\mathrm{O} 1$ and two $\mathrm{O} 3$ at a distance of $\sim 2 \AA$ forming a plane including $\mathrm{Xe}$, with dihedral angles inferior to $2^{\circ} . \mathrm{Z}^{\mathrm{eff}}$ for $\mathrm{Xe}$ is slightly more positive than that for $\mathrm{Si}$ in pure forsterite $(+2.85$; Table $\mathrm{S} 2)$. These charges significantly differ from the formal ones $(+4)$. This indicates a covalent character of Xe-O bonds involving the closest oxygens (O1 and $\mathrm{O} 3)$.

Regarding Xe for Mg substitutions, $\mathrm{Xe}_{\mathrm{Mg} 2}$ incorporation site was found more stable than $\mathrm{Xe}_{\mathrm{Mg} 1}$ by $1.05 \mathrm{eV}$. For both configurations, $\mathrm{Xe}$ is located in the former oxygen octahedron. Nevertheless, two oxygen atoms are located close to the sum of covalent radii of $\mathrm{Xe}$ and $\mathrm{O}$ with $\mathrm{Xe}-\mathrm{O}$ bond lengths $\sim 2 \AA$ whereas others $\mathrm{O}$ atoms are located significantly further (Fig. 2). The geometry is nearly linear with angle O3*-Xe-O3* close to $180^{\circ}$ for $\mathrm{Xe}_{\mathrm{Mg} 2}$ and $\mathrm{O} 2-\mathrm{Xe}-\mathrm{O} 2$ equal to $180^{\circ}$ for $\mathrm{Xe}_{\mathrm{Mg} 1}$. $\mathrm{Z}^{\text {eff }}$ for $\mathrm{Xe}$ in $\mathrm{X} \mathrm{e}_{\mathrm{Mg} 1}$ and $\mathrm{X} \mathrm{e}_{\mathrm{Mg} 2}$ are slightly higher than that for $\operatorname{Mg} 1(+1.95)$ and $\operatorname{Mg} 2(+2.10)$ in pure forsterite (Table S2). The small excess of $Z^{\text {eff }}$ of $\mathrm{Xe}$ in these configurations, compared to charge of $\mathrm{Mg}$ in pure forsterite, is 
228 counterbalanced by more negative $Z^{\text {eff }}$ for the two closest oxygens (Fig. 2) compared to pure 229 forsterite (Table S2). These results suggest a covalent character of Xe-O bonds involving 230 these oxygens.

For $\mathrm{Xe}_{\mathrm{i}}$, no oxygen atoms are located within the sum of covalent radii of $\mathrm{Xe}$ and $\mathrm{O}$

233 (Fig. 3). $\mathrm{Z}^{\text {eff }}$ for $\mathrm{Xe}$ is close to 0 indicating that $\mathrm{Xe}$ is nearly neutral in this configuration. 234 Small positive $Z^{\text {eff }}$ for $\mathrm{Xe}$, is counterbalanced by slightly more negative $Z^{\text {eff }}$ for surrounding oxygens (Fig. 3) compared to pure forsterite (Table S2). However, large Xe-O distances discard the possibility of covalency for Xe-O bond.

\subsubsection{Less stable configurations of Xe incorporation sites}

For $\mathrm{Xe}$ for $\mathrm{Si}$ substitution (which was found to best reproduce the experimental observations as further detailed), we investigated possible configurations by slightly moving

Xe within the oxygen tetrahedron visible in figure 1. We identified another configuration:

$243 \mathrm{Xe}_{\mathrm{Si}}(\mathrm{b})$, less stable than $\mathrm{Xe}_{\mathrm{Si}}$ by $0.54 \mathrm{eV}$, where $\mathrm{Xe}$ is quasi aligned with $\mathrm{O} 1$ and $\mathrm{O} 2(\mathrm{O} 1-\mathrm{Xe}-$

$244 \mathrm{O} 2=157^{\circ}$ ) though $\mathrm{Xe}$ remains inside the tetrahedron. For both $\mathrm{Xe}_{\mathrm{Si}}$ and $\mathrm{Xe} \mathrm{Si}_{\mathrm{Si}}(\mathrm{b})$ there exist non symmetric variant (respectively $\mathrm{Xe}_{\mathrm{Si}}$ ' and $\mathrm{Xe}_{\mathrm{Si}}(\mathrm{b})$ ') with $\mathrm{Xe}$ slightly shifted toward one of

246 the two $\mathrm{O} 3$ of the oxygen tetrahedron so that symmetry of the Xe incorporation sites is 247 broken. These non symmetric variants are slightly more stable than the corresponding 248 symmetric variants by $55 \mathrm{meV}$ (for $\mathrm{Xe}_{\mathrm{Si}}$ and $\mathrm{Xe}_{\mathrm{Si}}{ }^{\prime}$ ) and $54 \mathrm{meV}$ (for $\mathrm{Xe}_{\mathrm{Si}}(\mathrm{b})$ and $\mathrm{Xe}_{\mathrm{Si}}(\mathrm{b})$ '). 249 We checked that these results are not due to incomplete convergence or artefacts of 250 calculations. A major concern was Van der Waals interactions, which may be crucial for 251 calculations involving noble gases. We therefore repeated our calculations after adding a 252 correction for Van der Waals interactions via a pairwise atomic potential proportional to $\mathrm{R}^{-6}$ 253 (with $\mathrm{R}$ the distance between the atoms of a pair) as implemented by Barone et al. (2009) for 
254 DFT, based on results from Grimme (2006). We obtained similar geometries for the four 255 configurations and similar relative stabilities as previously found. We only observe a small 256 variation in differences of energies between configurations: from $0.54 \mathrm{eV}$ to $0.68 \mathrm{eV}$ between $257 \mathrm{Xe}_{\mathrm{Si}}$ and $\mathrm{Xe}_{\mathrm{Si}}(\mathrm{b})$ and from $55 \mathrm{meV}$ to $35 \mathrm{meV}$ and from $54 \mathrm{meV}$ to $46 \mathrm{meV}$, between 258 respectively $\mathrm{Xe}_{\mathrm{Si}}$ and $\mathrm{Xe}_{\mathrm{Si}}$ ' and $\mathrm{Xe}_{\mathrm{Si}}(\mathrm{b})$ and $\mathrm{Xe}_{\mathrm{Si}}(\mathrm{b})$ '.

\subsubsection{Comparison with other systems}

In our calculation, the most stable $\mathrm{Xe}$ for $\mathrm{Si}$ substitutions (i.e. $\mathrm{Xe}_{\mathrm{Si}}$ and $\mathrm{Xe}_{\mathrm{Si}}{ }^{\prime}$ ) present a planar geometry with Xe located on the face of the oxygen tetrahedron, surrounded by one $\mathrm{O} 1$ and two O3 (Fig. 1). As emphasized by Kalinowski et al. (2014), a planar structure is common for Xe compounds: in particular under the form of $\mathrm{XeO}_{4}$ units or chains present in $\mathrm{XeO}_{2}$ (Brock and Schrobilgen, 2011) $\mathrm{Xe}_{3} \mathrm{O}_{2}$ and $\mathrm{Xe}_{2} \mathrm{O}_{5}$ (Dewaele et al., 2016). This planar geometry was also proposed for Xe incorporation in fibrous silica (Kalinowski et al., 2014) and in $\alpha$-quartz via Xe for Si substitution (Probert, 2011). Other examples of incorporations associated with planar geometries have been reported on boron incorporation in olivine (Ingrin et al., 2014) and carbonate incorporation in fluor-apatite (Yi et al., 2013). In both cases, the carbon and boron atoms share significantly covalent bonds with surrounding oxygens. as Xe for Mg substitutions, present nearly linear geometries as in common compounds such as $\mathrm{XeF}_{2}$ or noble gas hydrides. For Xe for Si and $\mathrm{Xe}$ for $\mathrm{Mg}$ substitutions the nearest oxygen atoms have Xe-O bond 277 lengths within the sum of the covalent radii of Xe and $\mathrm{O}(\sim 2 \AA)$ (Figs. 1, 2). Also, the values 278 of $Z^{\text {eff }}$ indicate a certain degree of covalency of Xe-O bonds. Xe-O bonds are thus likely to be 
at least partially covalent for the closest oxygen atoms. This result implies that Xe can react

280 with olivine by oxidation processes.

Let us define:

$\Delta \mathrm{E}\left(\mathrm{Xe}_{\mathrm{Si}}\right)=\mathrm{E}\left(\mathrm{Xe}_{\mathrm{Si}}\right)-\mathrm{E}_{\mathrm{Xe}}-\mathrm{E}_{\mathrm{Fs}-\mathrm{Si}}$

$\Delta \mathrm{E}\left(\mathrm{Xe}_{\mathrm{Mg}}\right)=\mathrm{E}(\mathrm{Xe} \mathrm{Mg})-\mathrm{E}_{\mathrm{Xe}}-\mathrm{E}_{\mathrm{Fs}-\mathrm{Mg}}$

$\Delta \mathrm{E}\left(\mathrm{Xe}_{\mathrm{i}}\right)=\mathrm{E}\left(\mathrm{Xe}_{\mathrm{i}}\right)-\mathrm{E}_{\mathrm{Xe}}-\mathrm{E}_{\mathrm{Fs}}$

where $\mathrm{E}\left(\mathrm{Xe} \mathrm{e}_{\mathrm{Si}}\right), \mathrm{E}\left(\mathrm{Xe} \mathrm{e}_{\mathrm{Mg}}\right), \mathrm{E}\left(\mathrm{Xe}_{\mathrm{i}}\right)$ are the calculated energies for the cell used to simulate the different type of incorporation mechanisms $\left(\mathrm{Xe}_{\mathrm{Si}}, \mathrm{Xe}_{\mathrm{Mg}}\right.$ and $\left.\mathrm{Xe}_{\mathrm{i}}\right) . \mathrm{E}_{\mathrm{Xe}}$ is the energy of an isolated $\mathrm{Xe}$ atom. $\mathrm{E}_{\mathrm{Fs}-\mathrm{Si}}$ and $\mathrm{E}_{\mathrm{Fs}-\mathrm{Mg}}$ are the energies of the forsterite cell with one neutral $\mathrm{Si}$ or $\mathrm{Mg}$ vacancy (the atomic structure was fully relaxed) and $\mathrm{E}_{\mathrm{Fs}}$ is the energy of a pure forsterite cell. The calculated $\Delta \mathrm{E}$ values are reported in table 2 and represent the energy of the various incorporations in a forsterite presenting $\mathrm{Si}$ and $\mathrm{Mg}$ vacancies. Occurrence of $\mathrm{Si}$ and $\mathrm{Mg}$ vacancies in synthetic forsterite samples is suggested by the observation of related hydroxylated point defects (e.g. Lemaire et al. 2004, Balan et al. 2011, Ingrin et al. 2013, Balan et al. 2017, Blanchard et al. 2017). How the present $\Delta \mathrm{E}$ values can be compared to measurements is questionable. Indeed, besides the fact that the vacancies in the calculations are neutral, temperature effects are not included. Both effects are expected to be relevant

300 (Verna and Karki, 2009). That said, according to table 2, Xe incorporation in the Si vacancy 301 site $\left(\mathrm{Xe}_{\mathrm{Si}}\right)$ is more stable than $\mathrm{Mg}$-vacancy $\left(\mathrm{Xe}_{\mathrm{Mg}}\right)$ and interstitial $\left(\mathrm{Xe}_{\mathrm{i}}\right)$ incorporations. $\mathrm{A}$ 302 different conclusion would be reached if considering forsterite without vacancies. In this case 303 the relative stability would be dominated by the formation energy of the vacancy itself, which 
304 is higher for Si than for Mg (Béjina et al., 2000, Stashans and Flores, 2013), as can be seen in 305 Table 2 by comparing:

$306 \Delta \mathrm{E}_{\mathrm{v}}(\mathrm{Si})=\mathrm{E}_{\mathrm{Fs}-\mathrm{Si}}-\mathrm{E}_{\mathrm{Fs}}+\mathrm{E}_{\mathrm{Si}}$

$307 \Delta \mathrm{E}_{\mathrm{v}}(\mathrm{Mg})=\mathrm{E}_{\mathrm{Fs}-\mathrm{Mg}}-\mathrm{E}_{\mathrm{Fs}}+\mathrm{E}_{\mathrm{Mg}}$,

308 where $\mathrm{E}_{\mathrm{Si}}$ and $\mathrm{E}_{\mathrm{Mg}}$ are the energies of one atom of $\mathrm{Si}$ and $\mathrm{Mg}$ in the equilibrium diamond and 309 hcp bulk, respectively.

310 The relative stability of the three different incorporation mechanisms (Table 2), $311 \Delta \mathrm{E}\left(\mathrm{Xe}_{\mathrm{Si}}\right)<\Delta \mathrm{E}\left(\mathrm{Xe}_{\mathrm{Mg}}\right)<\Delta \mathrm{E}\left(\mathrm{Xe}_{\mathrm{i}}\right)$, results from an interplay of oxidation state and strain 312 induced on the host structure. Although we cannot unambiguously disentangle these effects 313 and determine which one dominates, we note that there is a correlation between the value of $314 \Delta \mathrm{E}$ and the Xe oxidation estimated in Figs. 1-4: the more stable structures having the highest 315 Xe oxidation (as it would be expected if oxidation was the only stabilization mechanism at 316 play). On the other hand, the $\Delta \mathrm{E}$ ordering can simply reflect the fact that different inclusions correspond to different volume increase of the host forsterite: the more stable structures corresponding to the smaller volume increase (bottom panel of Fig.4), as will be discussed in 319 the next section.

\subsection{Cell parameters vs. Xe concentration}

For each configuration, relaxation was done at $0,2,5$ and $5.7 \mathrm{GPa}$ for 0.89 at \% Xe, 0.45 at $\%$ Xe and 0.40 at $\%$ Xe. Cell parameters are only shown at $0 \mathrm{GPa}$ and $5.7 \mathrm{GPa}$ (Fig. 4), but the overall trend is similar at $2 \mathrm{GPa}$ and $5 \mathrm{GPa}$ (Table S3). We observe an increase of 326 volume with increasing Xe content $(+1.6 \%$ for Xe for Si substitutions, of $+2.3 \%$ for Xe for $327 \mathrm{Mg}$ substitutions, and $+4 \%$ for Xe in interstitial site at $0 \mathrm{GPa}$ from 0 at $\%$ Xe to 0.89 at $\%$ 
$\mathrm{Xe}$ ). However, variations of each cell parameters are strongly dependent on the Xe incorporation site (Fig. 4), and this can help to determine the likeliest incorporation site.

Variations of cell parameters for $\mathrm{Xe}_{\mathrm{Si}}$ incorporation site reproduce the experimentally observed increase of cell parameter $a$ associated with very small variations of cell parameter $b$ (Sanloup et al., 2011) compared to the thermal equation of state of olivine (Liu and Li, 2006). Other incorporation mechanisms do not reproduce this concomitant evolution of $a$ and $b$. Experimental variations of cell parameter $c$ are strongly temperature dependent (Sanloup et al., 2011), therefore they are not used for comparison with calculations, as they are unlikely to be reproduced quantitatively by our calculations at $0 \mathrm{~K}$. In contrast, the relative variations of $a$ and $b$, between the pure and the Xe-bearing systems can be used to assess the concentration of $\mathrm{Xe}$ in olivine. For $\mathrm{Xe}_{\mathrm{Si}}$, calculated increase of cell parameter $a$ from 0 at $\%$ Xe to 0.40 at $\%$ $\mathrm{Xe}$, is about $0.4 \%$ at all investigated pressures. This increase is close to the experimentally observed one (i.e. $+0.2 \%$ at $2 \mathrm{GPa},+0.4 \%$ at $5 \mathrm{GPa}$ and $+0.2 \%$ at $5.7 \mathrm{GPa}$ ). Consequently the Xe content in olivine at high pressure and temperature, studied by Sanloup et al. (2011), can be estimated to be equal or slightly less than 0.40 at $\% \mathrm{Xe}$. We note that the Xe content thus determined does not significantly vary with pressure between $2 \mathrm{GPa}$ and $5.7 \mathrm{GPa}$.

\subsection{Raman spectra} bands of olivine at $822 \mathrm{~cm}^{-1}$ and $855 \mathrm{~cm}^{-1}$ are clearly visible for $\mathrm{Xe}_{\mathrm{Si}}$ and $\mathrm{Xe}_{\mathrm{Mg} 2}$ incorporation sites. For $\mathrm{Xe}_{\mathrm{i}}$ and $\mathrm{X} \mathrm{e}_{\mathrm{Mg} 1}$ these two olivine bands are mixed with other contributions linked to the presence of Xe. New well-resolved and intense Raman bands appear in the $650-800 \mathrm{~cm}^{-1}$ region for $\mathrm{Xe}_{\mathrm{Si}}$ and, although less intense, for $\mathrm{Xe}_{\mathrm{Mg} 1}$ (Fig. 5). All these new Xe-related Raman bands involve the nearest oxygens around Xe (described and indexed in Figs. 1, 2, 3). For 
$353 \mathrm{Xe}_{\mathrm{Si}}$, the $720 \mathrm{~cm}^{-1}$ band is linked to strong Xe-O1 stretching along the $a$ axis (and weak 354 stretching of $\mathrm{a} \mathrm{SiO}_{4}$ tetrahedron close to Xe also along $a$ axis), whereas the weak $685 \mathrm{~cm}^{-1}$ 355 band is linked to $\mathrm{Xe}-\mathrm{O} 2$ bending. For $\mathrm{Xe}_{\mathrm{Mg} 1}$ the $739 \mathrm{~cm}^{-1}$ band is linked to the two $\mathrm{Xe}-\mathrm{O} 2$ 356 twisting. A new well-resolved intense band is also visible for $\mathrm{Xe}_{\mathrm{Mg} 2}$ at $900 \mathrm{~cm}^{-1}$ linked to the 357 two Xe-O3* symmetrical stretching with a wagging component. The bands are visible in 358 parallel polarization along axis or planes corresponding to the maximal direction of the 359 associated vibrational modes (Fig. 5). For $\mathrm{Xe}_{\mathrm{i}}$ (which closest oxygen is only located at 2.66 $360 \AA$ ), no new intense band is observed.

For $\mathrm{Xe}_{\mathrm{Si}}$ and $\mathrm{Xe} \mathrm{eg}_{\mathrm{Mg}}$, lots of poorly resolved bands are visible below $650 \mathrm{~cm}^{-1}$, and 362 above $800 \mathrm{~cm}^{-1}$. These weak bands are linked to the high Xe polarizability, which implies that 363 Xe presence will be felt by all atoms of the cell. In order to test this hypothesis, we calculate 364 Raman spectra for lower Xe contents. Results for 0.11 at \% Xe are shown in figure 6. Weak 365 non-resolved bands below $650 \mathrm{~cm}^{-1}$ and above $800 \mathrm{~cm}^{-1}$ visible for 0.89 at \% Xe (Fig. 5) 366 disappear with decreasing Xe content. Furthermore, for all Xe incorporation sites, pure 367 forsterite bands are well identified for 0.11 at $\%$ Xe not only at $822 \mathrm{~cm}^{-1}$ and $855 \mathrm{~cm}^{-1}$ but 368 also at $340 \mathrm{~cm}^{-1}, 611 \mathrm{~cm}^{-1}, 882 \mathrm{~cm}^{-1}, 923 \mathrm{~cm}^{-1}, 964 \mathrm{~cm}^{-1}$ (Fig. 6) implying that the presence of 369 Xe is just felt locally as expected for a diluted defect.

For 0.11 at \% Xe, Raman bands induced by Xe are still visible for $\mathrm{Xe} \mathrm{Si}_{\mathrm{Si}}\left(\right.$ at $720 \mathrm{~cm}^{-1}$ ), $371 \mathrm{Xe}_{\mathrm{Mg} 2}\left(\right.$ at $\left.900 \mathrm{~cm}^{-1}\right)$, and $\mathrm{Xe}_{\mathrm{Mg} 1}\left(\right.$ at $\left.710 \mathrm{~cm}^{-1}\right)$. In contrast, spectra calculated for $\mathrm{Xe}_{\mathrm{i}}$ only 372 present minor variations compared to pure forsterite. Presence of Xe in interstitial site can 373 therefore not be evidenced by Raman spectroscopy.

We also computed Raman spectra for $\mathrm{Xe}_{\mathrm{Si}}{ }^{\prime}, \mathrm{Xe}_{\mathrm{Si}}(\mathrm{b})$ and $\mathrm{Xe}_{\mathrm{Si}}(\mathrm{b})$ ' for 0.89 at $\% \mathrm{Xe}$. 375 Spectra show well-defined Xe-related bands at $745 \mathrm{~cm}^{-1}$ for $\mathrm{Xe}_{\mathrm{Si}}, 748 \mathrm{~cm}^{-1}$ for $\mathrm{Xe}_{\mathrm{Si}}$ (b) and $376750 \mathrm{~cm}^{-1}$ for $\mathrm{Xe}_{\mathrm{Si}}$ (b)' (Fig. S2) similar to the Xe-related band at $720 \mathrm{~cm}^{-1}$ in Raman spectrum 377 computed for $\mathrm{Xe}_{\mathrm{Si}}$ (Fig. 5). 
The bands observed between $720 \mathrm{~cm}^{-1}$ and $750 \mathrm{~cm}^{-1}$ for Xe for Si substitutions and at

$379710 \mathrm{~cm}^{-1}$ for $\mathrm{Xe}_{\mathrm{Mg} 1}$ are good candidates to explain the new Raman band observed by Sanloup 380 et al. (2011) (Fig. 6), keeping in mind that only $\mathrm{Xe}_{\mathrm{Si}}$ reproduces observed variations of cell 381 parameters. Broadness of the experimental Raman band may be caused firstly by the 382 coexistence of $\mathrm{Xe}_{\mathrm{Si}}, \mathrm{Xe}_{\mathrm{Si}}{ }^{\prime}, \mathrm{Xe}_{\mathrm{Si}}(\mathrm{b})$ and $\mathrm{Xe}_{\mathrm{Si}}(\mathrm{b})$ ' at high temperature. It may also be caused by 383 the chemical complexity of San Carlos olivine (see for instance trace and major element 384 analyses of San Carlos olivine in Spandler and O'Neill, 2010). Indeed there exist a variety of 385 Si vacancies, which slightly differs in terms of structural configuration and electronic 386 properties due to $\mathrm{Fe}$ and trace elements. Distribution of Xe in these Si vacancies will lead to a 387 range of slightly different vibration modes and consequently to a broad Raman signal as 388 compared to the present ideal model. Eventually, the high temperature of measurement (1800 $389 \mathrm{~K}$ ) induces broadening of the bands (Kolesov and Geiger, 2004). In cases of band ascribed to 390 chemical defects, this broadening can highly depends on the interaction of the trace element 391 with its crystalline host (e.g. Balan et al., 2017). High temperature may also induce a shift in 392 Raman frequency, as observed for characteristic bands of forsterite (decrease of $15 \mathrm{~cm}^{-1}$ from $393273 \mathrm{~K}$ to $1473 \mathrm{~K}$, Kolesov and Geiger, 2004).

3.4.1 Xe concentration from Raman spectra

Our calculated Raman spectra can be used to approximate the experimental Xe content 398 in olivine. Raman spectrum was computed for 0.45 at $\% \mathrm{Xe}$ for $\mathrm{Xe}_{\mathrm{Si}}$ (Fig. 7). The intensity of 399 the Raman spectrum calculated for $\mathrm{Xe}_{\mathrm{Si}}$ was integrated within the four energy windows 400 shown in figure 7. The intensity was, first, normalized to the integrated intensity in window 401 "3" (corresponding to the characteristic olivine bands) and, then, the contribution from pure 402 forsterite was subtracted. The normalized integrated intensity of Xe-related bands is linearly 
related to the Xe content (Fig. 8). The corresponding value extracted from the measured

404 Raman spectrum of Xe-rich olivine (Sanloup et al., 2011) is 2.3, which corresponds to $\sim 0.2$ at $\% \mathrm{Xe}$ in figure 8 . This evaluation must be considered as a first approximation and only represents a lower limit due to the significant signal to noise ratio in the experimental spectrum. Comparing Raman spectroscopy and X-ray diffraction, the evaluation of Xe

408 content based on XRD-determined cell-parameters variation (Sec. 3.3) should be more 409 reliable.

\section{DISCUSSION}

This work brings new insights on Xe storage at depth, attesting the possibility of Xe

414 incorporation in olivine. We tested here three types of incorporation mechanisms: Xe for $\mathrm{Mg}$ and Xe for Si substitutions, and interstitial Xe. Only Xe for Si substitutions can reproduce the observed evolution of the cell parameters induced by Xe at different pressures (Sanloup et al., 2011): the increase of $a$ is substantially more important than the increase of $b$ (variations of $418 c$, which are strongly temperature dependent, are unlikely to be reproduced by zero 419 temperature calculations). Furthermore, Xe for Si substitutions induce new Raman bands between $720 \mathrm{~cm}^{-1}$ and $750 \mathrm{~cm}^{-1}$ comparable with the broad band centred at $786 \mathrm{~cm}^{-1}$ observed on Xe-rich San Carlos olivine (Sanloup et al., 2011). Besides these two main results,

422 calculations reported in Table 2 also indicate that Xe for Si substitution might be the most 423 stable from the energetic point of view. The results of table 2 are, however, to be taken only 424 as a temptative estimation of the energetics, since calculations do not include temperature 425 effects and consider vacancies as neutrally charged. Consequently, reactivity of Xe with the 426 olivine is explained by substitution of Xe with silicon inducing Xe oxidation via formation of 427 Xe-O bonds with an important degree of covalency. Presence of Fe and other redox sensitive 
trace elements may modulate the reactivity of Xe. Incorporation sites may also slightly change their geometries compared to pure forsterite as studied here.

Raman spectroscopy turns out to be a valuable tool for the study of Xe incorporation in minerals. According to our findings, the high Xe polarizability makes it possible to retrieve a Xe signature for 0.11 at $\% \mathrm{Xe}$, and likely below. Moreover, the strong polarization of the Xe-related bands could, in principle, allow to discriminate experimentally among different incorporation mechanisms.

As detailed in the introduction, evaluation of $\mathrm{Xe}$ content based on in situ measurements is strongly needed. The present calculations can be used to estimate the Xe content in olivine from the in situ measurements (Sanloup et al., 2011). This has been done in two independent ways: i) by comparing the calculated and the X-ray diffraction measured values of cell parameters; ii) by comparing the Xe-related Raman-band intensities. According to i) or ii), the $\mathrm{Xe}$ concentration is $\sim 0.40$ at $\% \mathrm{Xe}$ or $\sim 0.20$ at $\% \mathrm{Xe}$, respectively. We judge 0.40 at $\% \mathrm{Xe}$ to be more reliable and 0.20 at $\% \mathrm{Xe}$ should be simply used as a lower boundary. However, the qualitative agreement between the two values is very encouraging, suggesting that future improvements of the present simplified structural model (based on a simple model of iron-free olivine) could provide a theoretical calibration to determine Xecontent from Raman measurements.

Using previously determined Xe solubility value of $0.2-0.4$ at $\%$ for olivine, at 0.9 $\mathrm{GPa}$ and $1800 \mathrm{~K}$, and a value of $0.08 \mathrm{~mol} \% \mathrm{Xe}$ for a tholeitic melt at $1.5 \mathrm{GPa}$ and $1773 \mathrm{~K}$ (Schmidt and Keppler, 2002), we found a partition coefficient for olivine/tholeitic melt $\left({ }^{\text {ol. } / \text { melt }} \mathrm{D}_{\mathrm{Xe}}\right)$ of $2.5-5$. A value of ${ }^{\text {ol. } / \text { melt }} \mathrm{D}_{\mathrm{Xe}}$ close to, or higher than 1 , in agreement with Hiyagon and Ozima (1986) and Broadhurst et al. (1992), challenges the supposedly incompatible behaviour of Xe in olivine. However, our value of ${ }^{\text {ol./melt }} \mathrm{D}_{\mathrm{Xe}}$ significantly differs from Heber et al. (2007) $\left({ }^{\text {ol./melt }} \mathrm{D}_{\mathrm{Xe}}=6 \cdot 10^{-4}\right)$. Heber et al. (2007) evaluated the Xe content of 
453 olivine exclusively on regions free of bubbles and melt inclusions, on the basis that they 454 might have formed upon quenching at ambient conditions, and if so, did not reflect the 455 equilibrium at high pressure and temperature. In contrast Hiyagon and Ozima (1986) and 456 Broadhurst et al. (1992) extracted Xe by heating the whole sample. Our result thus questions 457 the actual quest for free-bubble analysis of recovered samples as a guaranty of reliable 458 estimates of Xe content at high pressure and temperature in corresponding melt or minerals. Sanloup et al. (2011) observed Xe incorporation in olivine approximately throughout 460 the entire range of lithospheric mantle $\mathrm{P} / \mathrm{T}$ conditions. Assuming that olivine represents $60 \%$ 461 of the mantle volume (Bina, 1998), and that $90 \%$ of the Earth's primordial Xe is missing from 462 the atmosphere (Ozima and Podosek, 1999), storing the entire amount of the 'Missing Xe' in 463 the olivine of the upper mantle requires a Xe content in olivine of $0.012 \mathrm{ppb}$. This estimate is 464 much lower than the solubility value of 0.4 at \% (i.e. $2.5 \mathrm{wt} \% \mathrm{Xe}$ ) found here, hence the entire amount of the 'Missing Xe' could be stored in the upper mantle.

Although more data are needed on the dependence of Xe solubility in olivine on olivine chemical composition (e.g. Fe and other trivalent cations), pressures and temperatures, 468 but also in other minerals, these preliminary results prove that storage of Xe at depth can no 469 longer be discarded in the 'Missing Xenon' issue.

To our knowledge, there is currently no data available on the potential isotopic

471 fractionation of Xe during incorporation in minerals. However, it could be a key to explain 472 particular terrestrial Xe isotopic compositions, such as the observed ${ }^{136} \mathrm{Xe}$ enrichment in 473 mantle xenoliths of Mt Quincan (North Queensland, Australia), Victoria (Southeastern 474 Australia) and Reunion Island, which cannot be explained by mass dependent fractionation 475 (Czuppon et al., 2009). 
479 We are grateful to Yves Noël for helpful discussions. Calculations were performed using the 480 IBM iDataPlex cluster of the UPMC. This work was supported by the European 481 Community's Seventh Framework Programme (FP7/2007-2013) under grant agreements no. 482312284 and 259649 (European Research Council starting grant to C. Sanloup).

483

484

485

486

487

488

489

490

491

492

493

494

495

496

497

498

499

500

501

\section{REFERENCES}

Anders E. and Owen T. (1977) Mars and Earth: Origin and Abundance of volatiles. Science 198, 453-465.

Avice G. and Marty B. (2014) The iodine-plutonium-xenon age of the Moon-Earth system revisited. Phil. Trans. Soc. A 372, 20130260-20130276.

Balan E., Ingrin J., Delattre S., Kovács I., Blanchard M. (2011) Theoretical infrared spectrum of OH-defects in forsterite. Eur. J. Mineral. 23, 285-292.

Balan E., Blanchard M., Lazzeri M., Ingrin J. (2017) Theoretical Raman spectrum and anharmonicity of tetrahedral $\mathrm{OH}$ defects in hydrous forsterite. Eur. J. Mineral. 29, 201-212.

98 Barone V., Casarin M., Forrer D., Pavone M., Sambi M. and Vittadini A. (2009) Role and 99 Effective Treatment of Dispersive Forces in Materials: Polyethylene and Graphite Crystals as 00 Test Cases. J. Comput. Chem. 30, 934-939.

502 Baroni S., de Gironcoli S., Dal Corso A. and Giannozzi P. (2001) Phonons and related crystal 
properties from density-functional perturbation theory, Rev. Mod. Phys. 73, 515-562.

Béjina F., Blanchard M., Wright K. and Price G.D. (2009) A computer simulation of the effect of pressure on Mg diffusion in forsterite. Phys. Earth Planet. Int. 172, 13-19.

Bina C. R. (1998) Olivine emerges from isolation, Nature 392, 650-653.

Blanchard M., Ingrin J., Balan E., Kovacs I., Withers A.C. (2017) Effect of iron and trivalent cations on $\mathrm{OH}-$ defects in olivine. Am. Mineral. 102, 302-311.

Britvin S. N., Kashtanov S. A., Krzhizhanovskaya M. G., Gurinov A. A., Glumov O. V., Strekopytov S., Kretser Y. L., Zaitsev A. N., Chukanov N. V. and Krivovichev S. V. (2015) Perovskites with the Framework-Forming Xenon. Angew. Chem. Int. Ed. 48, 14340-14344.

Broadhurst C. L., Drake M. J., Hagee B. E. and Bernatowicz T. J. (1992) Solubility and partitioning of $\mathrm{Ne}$, Ar, and $\mathrm{Xe}$ in minerals and synthetic basaltic melts., Geochim. Cosmochim. Acta 56, 709-723.

Brock D. S. and Schrobilgen G. J. (2011) Synthesis of the Missing Oxide of Xenon, $\mathrm{XeO}_{2}$, and its implications for Earth's Missing Xenon. J. Am. Chem. Soc. 133, 6265-6269.

Crépisson C., Blanchard M., Bureau H., Sanloup C., Withers A. C., Khodja H., Surblé S., Raepsaet C., Béneut K., Leroy C., Giura P. and Balan E. (2014) Clumped fluoride-hydroxyl defects in forsterite: Implications for the uppe-mantle. Earth and Planet. Sci. Lett 390, 287295. 
529 Czuppon G., Matsumoto T., Handler M. R. and Matsuda J.-I. (2009) Noble gases in spinel 530 peridotite xenoliths from Mt Quincan, North Queensland, Australia: undisturbed morb-type 531 noble gases in the subcontinental lithospheric mantle. Chem. Geol. 266, 19-28.

533 Dewaele A., Worth N., Pickard C. J., Needs R.J., Pascarelli S., Mathon O., Mezouar M. and 534 Irifune T. (2016) Synthesis and stability of xenon oxides $\mathrm{Xe}_{2} \mathrm{O}_{5}$ and $\mathrm{Xe}_{3} \mathrm{O}_{2}$ under pressure. $535 \quad$ Nature Chemistry 8, 784.

Gerken M. and Schrobilgen G. J. (2002) Solution Multi-NMR and Raman Spectroscopic 538 Studies of Thermodynamically Unstable XeO4. The First ${ }^{131}$ Xe NMR Study of a Chemically 539 Bound Xenon Species. Inorg. Chem., 41(2), 198-204.

541 Ghosez Ph., Michenaud J.-P. and Gonze X. (1998) Dynamical atomic charges: the case of $542 \mathrm{ABO}_{3}$ compounds. Phys. Rev. B 58, 6224-6240.

544 Giannozzi P., Baroni S., Bonini N., Calandra M., Car R., Cavazzoni C., Ceresoli D., Chiarotti 545 G.L., Cococcioni M., Dabo I., Dal Corso A., de Gironcoli S., Fabris S., Fratesi G., Gebauer 546 R., Gerstmann U., Gougoussis C., Kokalj A., Lazzeri M., Martin-Samos L. (2009) quantum 547 ESPRESSO: a modular and open-source software project for quantum simulations of 548 materials. J. Phys.: Condens. Matter 21, 395502-395521.

550 Grimme S. (2006) Semiempirical GGA-Type Density Functional Constructed with a Long551 Range Dispersion Correction. J. Comput. Chem. 27, 1787-1799. 
553 Gundersen G., Hedberg K. and Huston J. L. (1970) Molecular Structure of Xenon Tetroxide, $554 \quad \mathrm{XeO}_{4}$. J. Chem. Phys. 52, 812-813.

555

556 Hazen R. M. (1976) Effects of temperature and pressure on the crystal structure of forsterite. 557 Am. Mineral. 61, 1280-1293.

558

559 Heber V. S., Brooker R. A., Kelley S. P. and Wood B. J. (2007) Crystal-melt partitioning of 560 noble gases (helium, neon, argon, krypton, and xenon) for olivine and clinopyroxene. 561 Geochim. Cosmochim. Acta 71, 1041-1061.

562

563 Hermann A. and Schwerdtfeger P. (2014) Xenon Suboxides Stable under Pressure. J. Phys. 564 Chem. Lett. 5, 4336-4342.

565

566 Hiyagon H. and Ozima M. (1986) Partition of noble gases between olivine and basalt melt. 567 Geochim. Cosmochim. Acta 50, 2045-2057.

569 Holland G. and Ballentine C. J. (2006) Seawater subduction controls the heavy noble gas 570 composition of the mantle. Nature 441, 186-191.

571

572 Hopkinson L., Roberts S., Herrington R. and Wilkinson J. (1999) The nature of crystalline 573 silica from the TAG submarine hydrothermal mound, $26^{\circ} \mathrm{N}$ Mid Atlantic Ridge. Contrib 574 Mineral Petrol 137, 342-350. 
576 Ingrin J., Liu J., Depecker C., Kohn S.C., Balan E., Grant K.J. (2013) Low-temperature

577 evolution of $\mathrm{OH}$ bands in synthetic forsterite, implication for the nature of $\mathrm{H}$ defects at high 578 pressure. Phys. Chem. Minerals 40, 499-510.

580 Ingrin J., Kovacs I., Deloule E., Balan E., Blanchard M., Kohn S.C. and Hermann J. (2014) 581 Identification of hydrogen defects linked to boron substitution in synthetic forsterite and 582 natural olivine. Am. Mineral. 99, 2138-2141.

584 Kalinowski J., Räsänen M. and Gerber R. B. (2014) Chemically-bound Xenon in Fibrous 585 Silica. Phys. Chem. Chem. Phys. 16, 11658-11663.

Kolesov A. and Geiger C. A. (2004) A Raman spectroscopic study of Fe-Mg olivines. Phys. Chem. Minerals 31, 142-154.

590 Krumennacher D., Merrihue C. M., Pepin R. O. and Reynolds J. H. (1962) Meteoritic krypton 591 and barium versus the general isotopic anomalies in meteoritic xenon. Geochim. Cosmochim. 592 Acta 28, 231-249.

594 Kuroda P. K., Sherrill R. D. and Jackson K. C. (1977) Abundances and isotopic compositions 595 of rare gases in granites. Geochem. J. 11, 75-90.

596

597 Lazzeri M. and Mauri F. (2003) First-Principles Calculation of Vibrational Raman Spectra in 598 Large Systems: Signature of Small Rings in Crystalline $\mathrm{SiO}_{2}$. Phys. Rev. Lett. 90, 036401599036405. 
601 Lazzeri M. and Thibaudeau P. (2006) Ab initio Raman spectrum of the normal and disordered 602 $\mathrm{MgAl}_{2} \mathrm{O}_{4}$ spinel. Phys. Rev. B. 74, 140301-140305.

603

604 Lemaire C., Kohn S.C., Brooker R.A. (2004) The effect of silica activity on the incorporation 605 mechanism of water in synthetic forsterite: a polarised infrared spectroscopic study. Contrib. 606 Mineral. Petrol. 147, 48-57.

607

608

Liu W. and Li B. (2006) Thermal equation of state of $\left(\mathrm{Mg}_{0.9} \mathrm{Fe}_{0.1}\right)_{2} \mathrm{SiO}_{4}$ olivine. Phys. Earth 609 Planet. Int. 157, 188-195.

610

611 Matsubara K., Matsuda J., Nagao K., Kita I. and Taguchi S. (1988) Xe in amorphous silica: a 612 new thermometer in geothermal systems. Geophys. Res. Lett. 15(7), 657-660.

613

614 Matsuda J. and Matsubara K. (1989) Noble gases in silica and their implication for the 615 terrestrial “Missing” Xe. Geophys. Res. Lett. 16 (1), 81-84.

616

617 McKeown D., Bell M. I. and Caracas R. (2010) Theoretical determination of the Raman 618 spectra of single-crystal forsterite $\left(\mathrm{Mg}_{2} \mathrm{SiO}_{4}\right)$. Am. Mineral. 95, 980-986.

619

620 Noël Y., Catti M., d'Arco P. and Dovesi R. (2006) The vibrational frequencies of forsterite $621 \mathrm{Mg}_{2} \mathrm{SiO}_{4}$ : an all-electron ab initio study with the CRYSTAL code. Phys. Chem. Minerals 33, $622 \quad 383-393$.

623

624 Ozima M. and Podosek F. A. (1999) Formation age of Earth from 129I/127I and 244Pu/238U 625 systematics and the missing Xe. J. Geophys. Res. 104 (B11), 25493-25499. 
627 Perdew J.P., Burke K. and Ernzerhof M. (1996) Generalized gradient approximation made 628 simple. Phys. Rev. Lett. 77, 3865-3868.

629

630 Probert M.I.J. (2010) An ab initio study of xenon retention in $\alpha$-quartz. J. Phys.: Condens.

631 Matter 22, 025501-025511.

632

633 Pujol M., Marty B. and Burgess R. (2011) Chondritic-like xenon trapped in Archean rocks: A 634 possible signature of the ancient atmosphere. Earth Planet. Sci. Lett. 308, 298-306.

635

636 Pujol, M., Marty, B. and Burgess R. (2013) Reply to comment on "Chondritic-like xenon 637 trapped in Archean rocks: A possible signature of the ancient atmosphere" by Pujol, M., 638 Marty, B., Burgess, R. by Pepin, R.O., Earth and Planetary Science Letters 308 (2011) 298639306. Earth Planet. Sci. Lett. 371, 296-298.

640

641 Sanloup C., Hemley R. J. and Mao H-K. (2002) Evidence for xenon silicates at high pressure 642 and temperature. Geophys. Res. Lett. 29, 1883-1887.

643

644 Sanloup C., Schmidt B. C., Chamorro Perez E. M., Jambon A., Gregoryanz E. and Mezouar 645 M. (2005) Retention of Xenon in Quartz and Earth's Missing Xenon. Science 310, 11746461177.

647

648 Sanloup C., Schmidt B. C., Gudfinnsson G., Dewaele A. and Mezouar M. (2011) Xenon and 649 Argon: a contrasting behaviour in olivine at depth. Geochim. Cosmochim. Acta 75, 62716506284. 
652 Schmidt B.C. and Keppler H. (2002) Experimental evidence for high noble gas solubilities in 653 silicate melts under mantle pressures, Earth Planet. Sci. Lett. 195, 277-290.

654

655 Spandler C. and O’Neill H. St.C. (2010) Diffusion and partition coefficients of minor and 656 trace elements in San Carlos olivine at $1,300^{\circ} \mathrm{C}$ with some geochemical implications. Contrib. 657 Mineral. Petrol. 159, 791-818.

658

659 Stashans A. and Flores Y. (2013) Modelling of neutral vacancies in forsterite mineral Int. J. 660 Mod. Phys. B. 27, 1350141.

661

662 Troullier N. and Martins J. L. (1991) Efficient pseudopotentials for plane-wave calculations. 663 Phys. Rev. B 43, 1993-2006.

664

665 Verma A. K. and Karki B. B. (2009) Ab initio investigations of native protonic point defects 666 in $\mathrm{Mg}_{2} \mathrm{SiO}_{4}$ polymorphs under high pressure. Earth Planet. Sci. Lett. 285, 140-149.

667

668 Yi H., Balan E., Gervais C., Segalen L., Fayon F., Riche D., Person A., Morin G., Guillaumet 669 M., Blanchard M., Lazzeri M. and Babonneau F. (2013) A carbonate-fluoride defect model 670 for carbonate-rich fluorapatite. Am. Mineral. 98, 1066-1069.

671

672

673

674

675 
676 Table 1: Bond lengths and cell parameters of Xe reference compounds: $\mathrm{XeO}_{4}$ molecule and $677 \mathrm{Xe}_{3} \mathrm{O}_{2}$ at $97 \mathrm{GPa}$.

\begin{tabular}{|c|c|c|c|}
\hline $\mathrm{XeO}_{4}$ & This study & Calc. $^{a}$ & Exp. $^{\text {b }}$ \\
\hline $\mathrm{Xe}-\mathrm{O}(\AA)$ & 1.77 & 1.82 & 1.736 \\
\hline $\mathrm{Xe}_{3} \mathrm{O}_{2}$ & This study & Calc. $^{c}$ & Exp. $^{c}$ \\
\hline $\mathrm{a}(\AA)$ & 8.377 & 8.388 & 8.457 \\
\hline $\mathrm{b}(\AA)$ & 3.206 & 3.195 & 3.166 \\
\hline c $(\AA)$ & 4.881 & 4.881 & 4.904 \\
\hline $\mathrm{Xe}^{4+}-\mathrm{O}(\AA)$ & 2.01 & 2.01 & 1.99 \\
\hline $\mathrm{Xe}^{0}-\mathrm{Xe}^{0}(\AA)$ & 3.05 & 3.05 & 3.06 \\
\hline $\mathrm{Xe}^{4+}-\mathrm{Xe}^{0}(\AA)$ & $2.95-3.00$ & $2.95-3.00$ & $2.96-3.01$ \\
\hline$X e^{4+}-X^{4+}(\AA)$ & 3.21 & 3.19 & 3.17 \\
\hline
\end{tabular}

$678 \quad{ }^{\mathrm{a}}$ Probert, 2010, ${ }^{\mathrm{b}}$ Gundersen et al. (1970), and ${ }^{\mathrm{c}}$ Dewaele et al. (2016).

679

680

681

682

683

684

685

686

687

688

689

690

691

692

693

694 
695 Table 2: Formation energies for the different $\mathrm{Xe}$ incorporation mechanisms. $\Delta \mathrm{E}$ and $\Delta \mathrm{E}_{\mathrm{v}}$ are 696 defined in the text.

697

\begin{tabular}{l|l||l|l} 
& $\Delta \mathrm{E}(\mathrm{eV})$ & & $\Delta \mathrm{Ev}(\mathrm{eV})$ \\
\hline $\mathrm{Xe}_{\mathrm{Si}}$ & -0.12 & $\mathrm{Si}$ & 15.2 \\
\hline $\mathrm{Xe}_{\mathrm{Mg} 1}$ & 2.75 & $\mathrm{Mg}_{1}$ & 8.9 \\
\hline $\mathrm{Xe}_{\mathrm{Mg} 2}$ & 1.48 & $\mathrm{Mg}_{2}$ & 10.0 \\
\hline $\mathrm{Xe}_{\mathrm{i}}$ & 8.21 & &
\end{tabular}

698

699

700

701

702

703

704

705

706

707

708

709

710

711

712

713

714

715

716

717

718

719

720 


\section{Figure captions}

Figure 1: Calculated structure of the $\mathrm{Xe}_{\mathrm{Si}}$ incorporation site in forsterite. Note the localization

of the $\mathrm{Xe}$ on the face of the oxygen tetrahedron. Relevant $\mathrm{O}-\mathrm{Xe}-\mathrm{O}$ angles, $\mathrm{Xe}-\mathrm{O}$ bond length, and one third of the trace of the Born effective charge tensor $\left(Z^{\mathrm{eff}}\right)$ are indicated. $a, b$, and $c$ forsterite lattice parameters are along $\mathrm{x}, \mathrm{y}$, and $\mathrm{z}$ axes, respectively.

Figure 2: Calculated structure of the $\mathrm{Xe}_{\mathrm{Mg} 1}$ and $\mathrm{Xe}_{\mathrm{Mg} 2}$ incorporation sites (see also Fig.1 caption). $\mathrm{O} 3$ and $\mathrm{O} 3 *$ atoms are equivalent in pure forsterite.

Figure 3: Calculated structure of the $\mathrm{Xe}_{\mathrm{i}}$ incorporation site (see also Fig.1 caption). $\mathrm{O} 3 \mathrm{a} / \mathrm{O} 3 \mathrm{~b} / \mathrm{O} 3 \mathrm{c} / \mathrm{O} 3 \mathrm{~d}$ atoms (as $\mathrm{O} 2 / \mathrm{O} 2 *$ and $\mathrm{O} 1 / \mathrm{O} 1 *$ ) are equivalent in pure forsterite. For clarity, only details for $\mathrm{O}$ within $3.05 \AA$ around Xe are given.

Figure 4: Calculated evolution of cell parameters $a, b, c$ and volume as a function of Xe content at $0 \mathrm{GPa}$ (black symbols) and $5.7 \mathrm{GPa}$ (orange symbols). Dotted lines are guides for 737 the eyes.

Figure 5: Calculated Raman spectra of the different stable configurations of Xe incorportation in forsterite $(0.89$ at \% Xe) and pure forsterite vs. measurements (exp.) from Sanloup et al.

741 (2011). The spectrum on Xe-rich olivine was recorded at $0.9 \mathrm{GPa}$ after quenching $\mathrm{T}$ from

$7421800 \mathrm{~K}$. The spectrum on Xe-free olivine was recorded at $0.9 \mathrm{GPa}$ and $300 \mathrm{~K}$ before heating 743 (i.e. before reaction of Xe with olivine). The labels associated with some calculated Xe744 related bands indicate strong polarization: the bands are visible only in parallel polarization 745 along specific axes (corresponding to the $a, b, c$ lattice parameters). 
747 Figure 6: Calculated Raman spectra of the different stable configurations of Xe incorporation 748 in forsterite $(0.11$ at $\% \mathrm{Xe})$ and pure forsterite vs. measurements (exp.) from Sanloup et al. 749 (2011).

751 Figure 7: Calculated Raman spectra for $\mathrm{Xe}_{\mathrm{Si}}$ for various Xe content. Measurements (exp.) 752 from Sanloup et al. (2011). The four energy windows (1, 2, 3 and 4) used to integrate the 753 intensity of Raman bands (see text) are shown.

754

755 Figure 8: Normalized integrated intensity of Xe-related Raman bands for $\mathrm{Xe}_{\mathrm{Si}}$ incorporation 756 site as a function of Xe content from the present calculations. The dotted line is a linear fit. 757 The horizontal dashed line indicates value for experimental Raman spectrum of Xe-rich 758 olivine from Sanloup et al. (2011).

759

760

761

762

763

764

765

766

767

768

769

770

771

772 
775

776

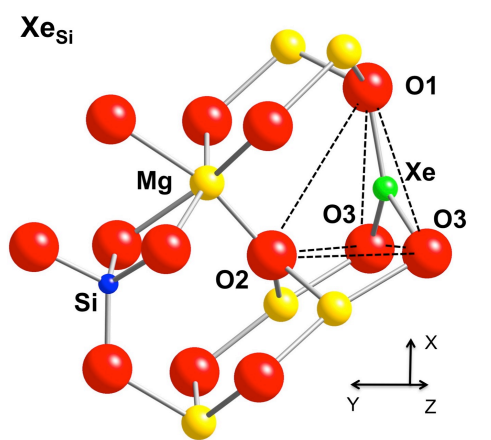

O1-Xe-03 $=128.3^{\circ}$

O3-Xe-O3 = 103. $3^{\circ}$

Xe-01 = $1.99 \AA$

$\mathrm{Xe}-\mathrm{O} 3=2.00 \AA$

$\mathrm{Xe}-\mathrm{O} 2=2.65 \AA$

$Z^{\text {eff }: ~} \mathrm{Xe}=+2.89$

$\mathrm{O} 1=-1.64$

$\mathrm{O} 3=-1.41$

$\mathrm{O} 2=-1.81$

777

778

779

780

781

782

783

784

785

786

787

788

789

790

791

792

793

794 
796

797

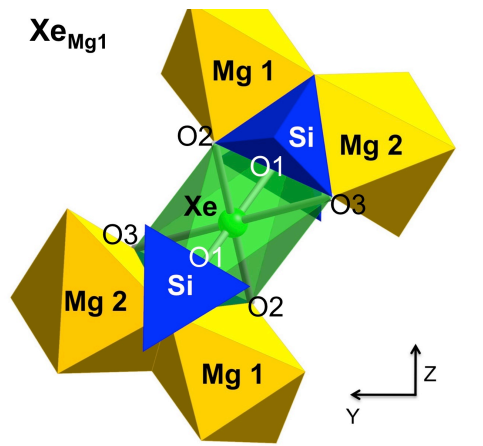

O2-Xe-O2 $=180.0^{\circ}$

$\mathrm{Xe}-\mathrm{O} 2=2.15 \AA$

$\mathrm{Xe}-01=2.64 \AA$

$\mathrm{Xe}-\mathrm{O} 3=2.70 \AA$

$Z^{\text {eff }}: \quad \mathrm{Xe}=+2.26$

$\mathrm{O} 2=-1.82$

$01=-1.77$

$\mathrm{O} 3=-1.68$

798

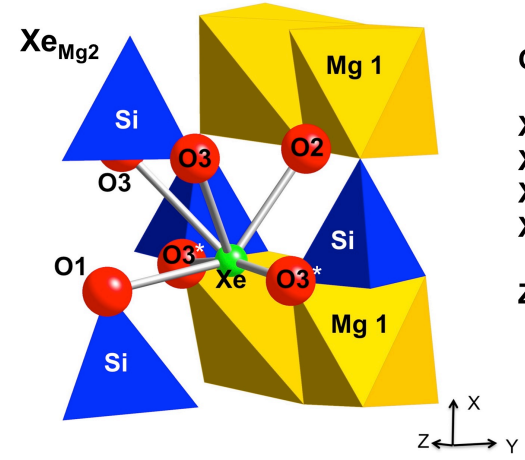

O3*-Xe-O3* $=165.4^{\circ}$

$\mathrm{Xe}^{-\mathrm{O3}^{*}}=2.08 \AA$

$\mathrm{Xe}-\mathrm{O} 2=2.66 \AA$

$\mathrm{Xe}-01=2.79 \AA$

$\mathrm{Xe}-\mathrm{O} 3=3.03 \AA$

Zeff : $\mathrm{Xe}=+2.36$

$\mathrm{O}^{*}=-1.86$

$\mathrm{O} 2=-1.71$

$01=-1.78$

$\mathrm{O} 3=-1.70$

799

800

801

802

803

804

805

806

807

808

809

810

811 
Figure 3

813

814

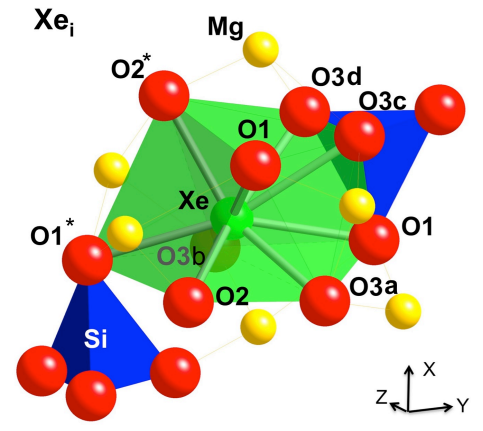

Xe-03a $=2.66 \AA$

$\mathrm{Xe}^{-O 2}{ }^{*}=2.66 \AA$

$\mathbf{X e - O 3 b}=2.79 \AA$

Xe-O1* $=2.84 \AA$

$\mathrm{Xe}-\mathrm{O} 3 \mathrm{c}=2.90 \AA$

$Z^{\text {eff }}: X e=+0.30$

$\mathrm{O} 3 \mathrm{a}=-1.82$

$\mathrm{O} 2^{*}=-1.78$

$03 b=-1.76$

$01^{*}=-1.83$

$\mathrm{O} 3 \mathrm{c}=-1.79$

815

816

817

818

819

820

821

822

823

824

825

826

827

828

829

830

831

832 
Figure 4

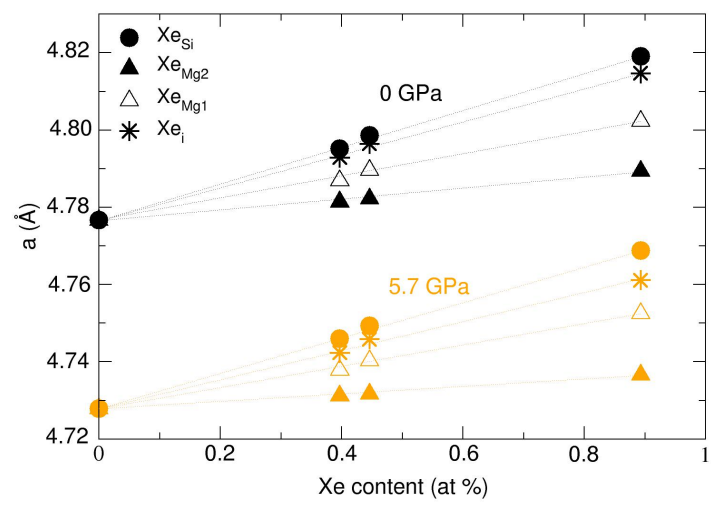

834

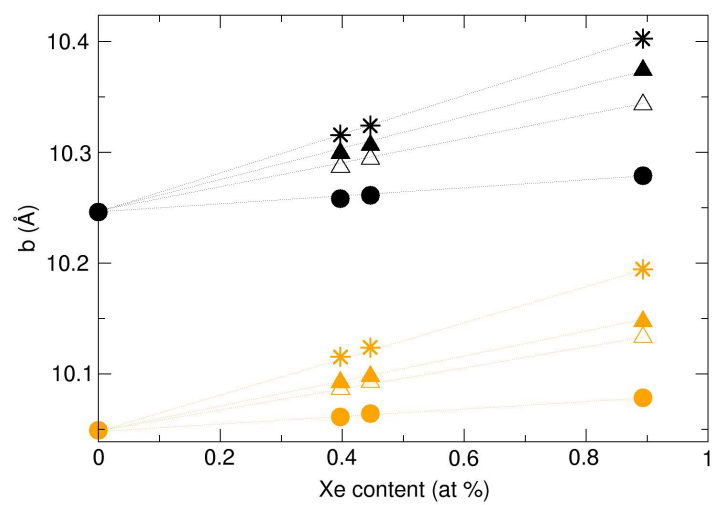

835

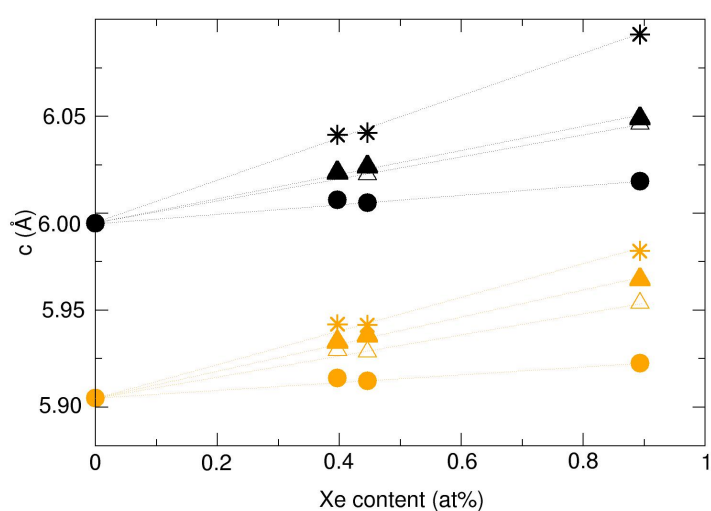

836

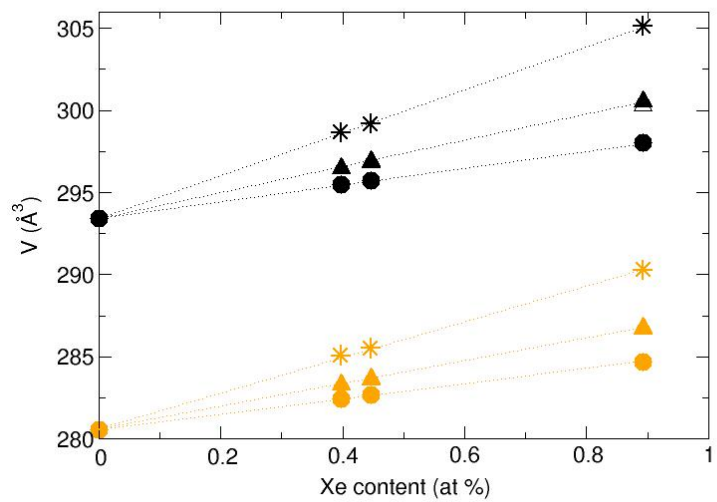


839

840

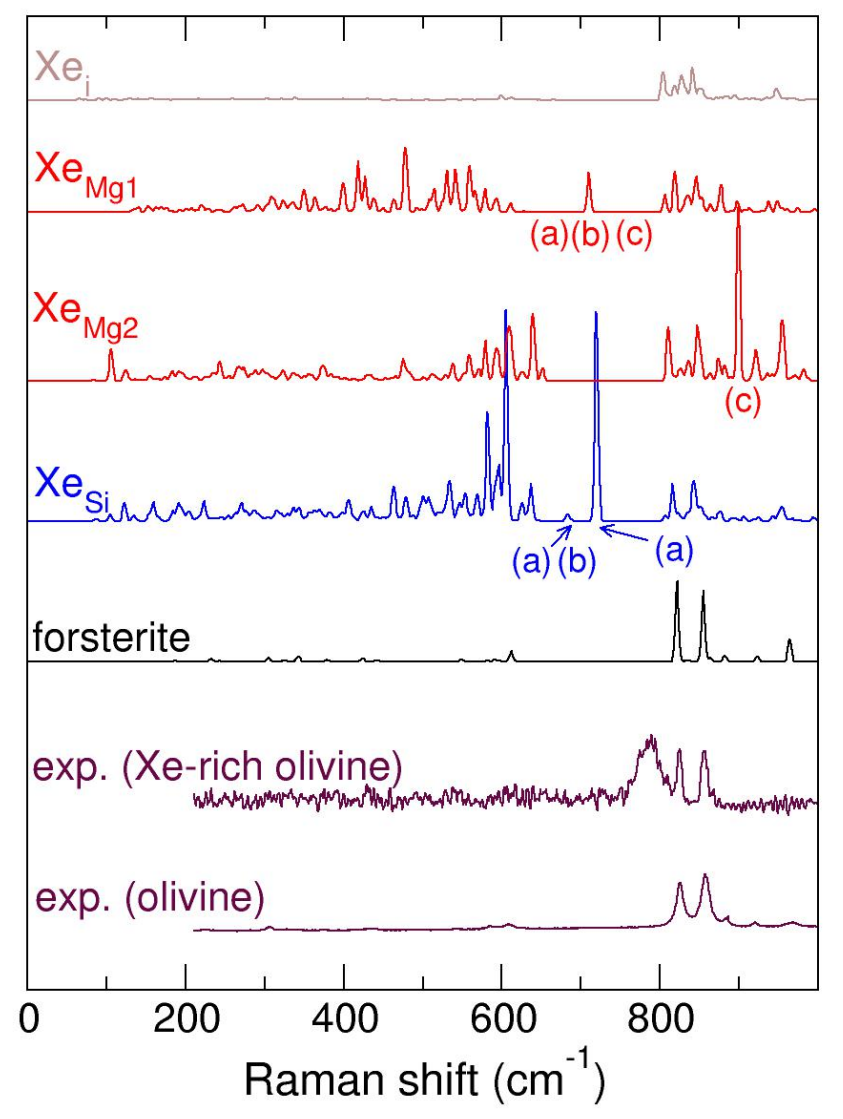

841

842

843

844

845

846

847

848

849

850

851

852

853

854 
856

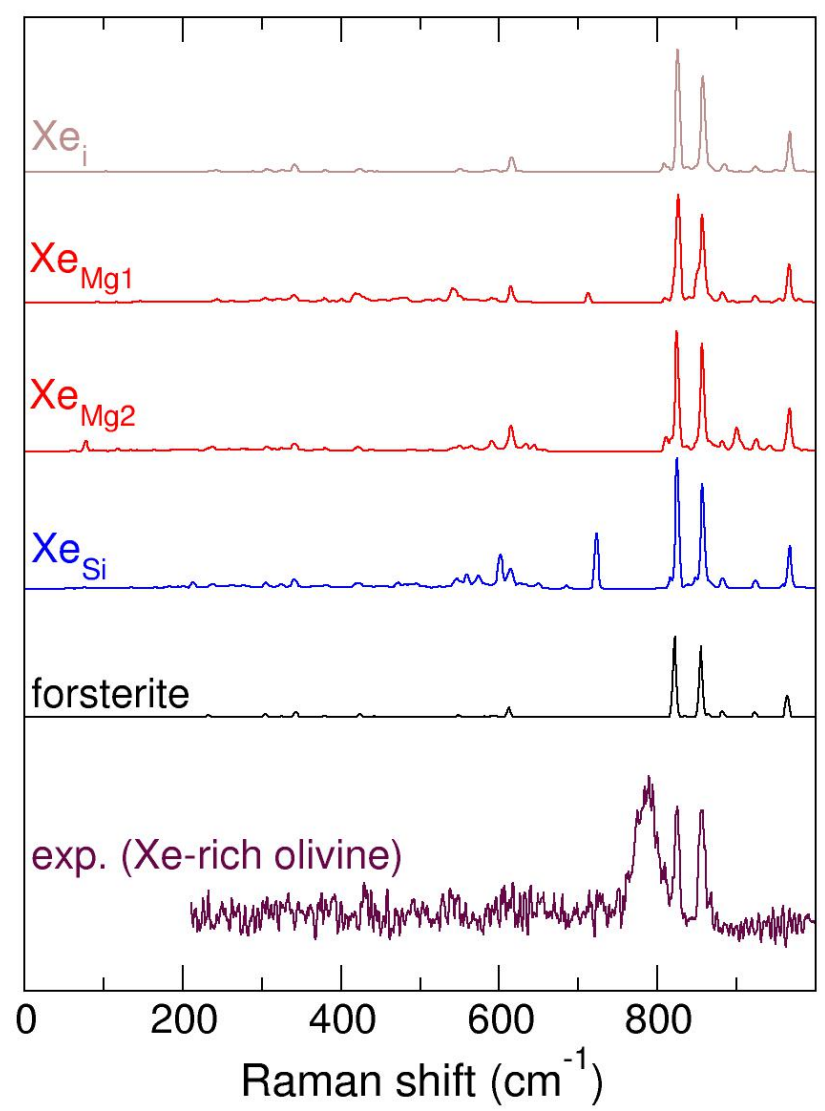

858

859

860

861

862

863

864

865

866

867

868

869 
871

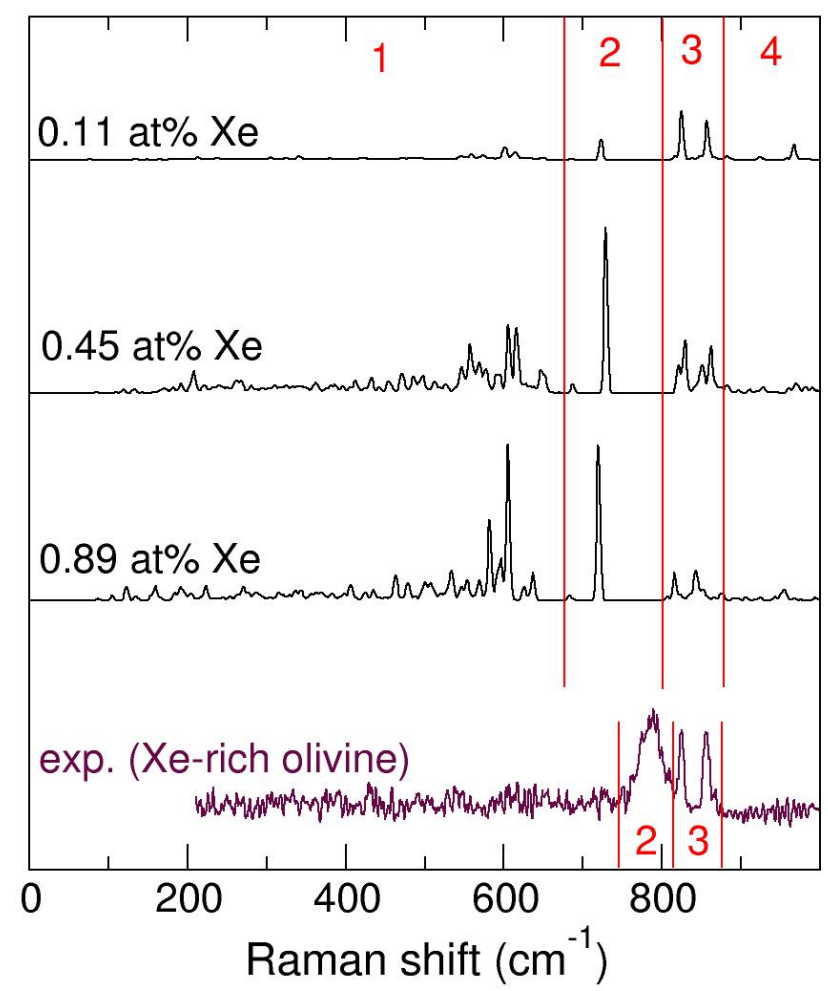

873

874

875

876

877

878

879

880

881

882

883

884

885 
Figure 8

887

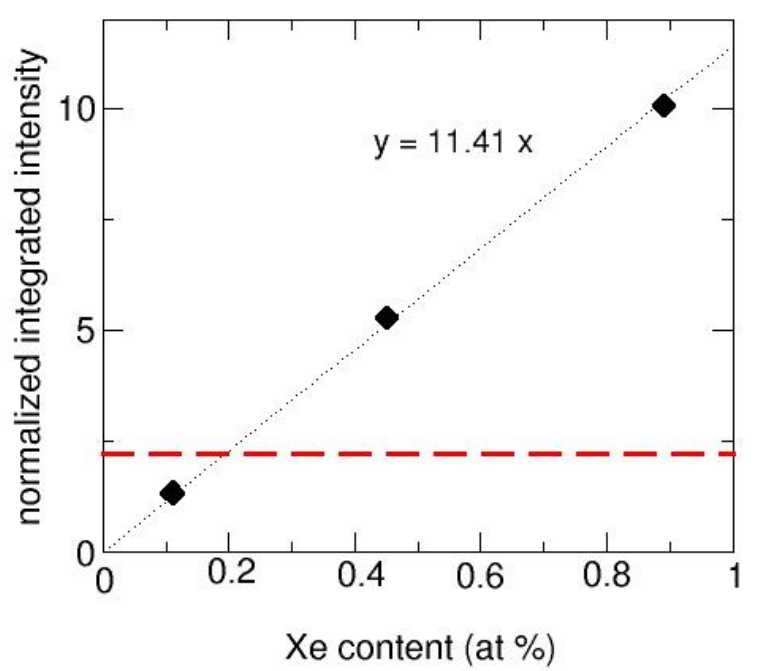

